\title{
PEMANFAATAN TEKNOLOGI INFORMASI DALAM PELAKSANAAN PEMBELAJARAN DENGAN MEDIA WEBSITE DAN YOUTUBE CHANNEL
}

\section{Raden Yudhy Pradityo Setiadiputra ${ }^{1}$}

\section{Keywords :}

Pengembangan Kompetensi

Website

Youtube Channel

Media Pembelajaran

\section{Corespondensi Author}

${ }^{1}$ SDM, BPSDM Provinsi DKI Jakarta

J1.Abdul Muis No.66 Lantai 6 Jakarta

Email: yudhypradityo@gmail.com

\begin{abstract}
Abstrak. Pengembangan kompetensi merupakan salah satu syarat mutlak untuk meningkatkan kualiats dari suatu organisasi termausk instansi pemerintah. Sumber daya manusia merupakan asset terpenting dalam suatu organisasi guna meningkatkan kualitas organisasi tersebut. Berkenaan dengan hal tersebut, pengembangan komptensi saat ini sudha dapat dilakukan dengan berbagai cara. Mengingat saat ini sudah memasuki era dispruptif teknologi, maka pelaksanana pengembangan kompetensi dapat dilakukan dengan berbagai cara namun tetap perlu dilakukan secara terintegrasi agar dalam pelaksanaannya tetap terkendali dan sesuai dengan apa yang diharapkan. Mengingats emakin tingginya penggunaan internet dan sata ini sedang memasuki pandemic covid-19, pembelajaran jarak jauh merupakan salah satu cara yang ditempuh guna tetap melaksanakan pengembangan kompetensi pegawai termasuk bagi ASN dilingkungan instansi pemerintah. Menggunaka pembelajaran melalui media website dan youtube channel saat ini merupakan hal yang lumrah, dimana para ASN dapat belajar mandiri sesuai dengan keinginnannya, namun tetap sesuai koridor yang diharapkan. Penggunaan website dan youtube channel merupakan hal yang mudah dan dapat diakses oleh siapapun mengingat perkembangan teknologi informasi dewasa ini sudah berkembang dengan sangat pesat.
\end{abstract}

\section{Pendahuluan}

Sumber daya manusia merupakan salah satu unsur terpenting dalam berkembangnya suatu organisasi. Upaya peningkatan dan perkembangan organisasi pemerintah kearah yang semakin baik, pemerintah telah menerbitkan Undang - undang Nomor 5 Tahun 2004 tentang Aparatur Sipil Negara beserta Peraturan Pemerintah yang mengatur tentang kompetensi para Aparatur Sipil Negara (ASN).

Organisasi pemerintah sebagai institusi pelayan harus terus berupaya untuk berkembang. Hal ini agar organisasi pemerintah dapat terus memenuhi kebutuhan masyarakat akan pelayanan yang dilakukan oleh pemerintah. Guna memenuhi hal tersebut, pemerintah selalu berupaya untuk meningkatkan kompetensi dari setiap sumber daya manusia yang dimiliki. Pengembangan kompetensi ASN dilingkungan organsiasi pemerintah saat ini sudah berkembang dengan cukup baik. Perkembangan pelaksanaan pengembangan kompetensi ASN saat ini sudah mulai mengikuti dengan perkembangan teknologi informasi yang ada.

Perkembangan teknologi informasi yang ada dewasa ini dalam pelaksanana pengembangan kompetensi ASN adalah dengan 


\section{Raden Yudhy Pradityo Setiadiputra. Pemanfaatan Teknologi Informasi Dalam Pelaksanaan Pembelajaran Dengan Media Website Dan Youtube Channel}

memanfaatan teknologi - teknologi informasi dalam penyelenggaraannya. Teknologi informasi yang digunakan antara lain, dengan menggunakan komputerisasi pembelajaran, media internet sebagai dasar untuk pelaksanaan pengembangan kompetensi jarak jauh. Pengembangan kompetensi jarak jauh ini dapat bermanfaat baik bagi organisasi pemerintah penyelenggara pengembangan kompetensi sendiri maupun bagi organisasi pemerintah tempat ASN bekerja, maupun dapat bermanfata bagi ASN itu sendiri.

Pemerintah Provinsi DKI Jakarta sejak tahun 2017 telah berupaya untuk mengembangan tenologi pengembangan kompetensi jarak jauh (e-learning). Pemanfaatan e-learning dilingkungan Pemerintah Provinsi DKI Jakarta saat ini terus dikembangkan kearah yang lebih baik lagi, sehingga dapat menjangkau lebih banyak lagi ASN untuk ikut serta dalam pengembangan kompetensi, semakin banyaknya pengembangan kompetensi yang dapat dilakukan menggunakan metode jarak jauh ini serta untuk peningkatan pelaksanaan efektifitas maupun efisiensi pengelolaan pengembangan kompetensi.

Guna mendukung pelaksanaan pengembangan kompetensi ASN di lingkungan Pemerintah Provinsi DKI Jakarta kearah yang lebih baik lagi serta peningkatan pemanfaatan teknologi informasi dalam pelaksanaannya setiap Widyaiswara dituntut untuk tidak tertinggal dalam penguasaan teknologi informasi. Sejak tahun 2016 penulis telah mengembangkan website penulis yang awalnya digunakan untuk kepentingan pribadi penulis. Akan tetapi dengan berjalannnya waktu dan melihat kebutuhan akan teknologi informasi dalam pengembangan kompetensi ASN yang semakin penting, penulis merasa perlu untuk pemanfaatan website dalam pelaksanaan pengembangan kompetensi di kelas. Saat ini telah berkembang website tersebut selain sebagai bahan pendistribusian bahan tayang, modul, artikel maupun peraturan - peraturan juga telah dapat digunakan sebagai sarana tryout online dan telah berkembang pula media youtube channel penulis yang digunakan sebagai media simulasi yang lebih interaktif, media publikasi dari produk - produk pengembangan kompetensi ASN.

Berdasarkan uraian diatas, maka jenis kegiatan yang telah dilaksanakan adalah Pemanfaatan Teknologi Informasi dalam
Pelaksanaan Pembelajaran dengan Media Website dan Youtube Channel, baik bagi para Aparatur Sipil Negara dilingkungan Pemerintah Provinsi DKI Jakarta, Pemerintah Pusat/Pemerintah Daerah maupun bagi masyarakat secara umum, yaitu :

1) Pemanfaatan website dalam pendistribusian bahan tayang, modul - modul maupun artikel - artikel yang disusun oleh penulis maupun rekan penulis;

2) Pemanfaatan website dalam menghimpun peraturan - peraturan terkait kepegawaian dan keuangan;

3) Pemanfaatan website yang digunakan untuk pelaksanaan tryout online ujian pengadaan barang/jasa pemerintah tryout online CPNS;

4) Pemanfaatan youtube channel yang digunakan untuk mensimulasikan secara lebih interaktif terkait pengembangan kompetensi ASN.

Manfaat pelaksanaan kegiatan ini adalah:

1) Pendistribusian bahan tayang, modul modul maupun artikel - artikel yang disusun oleh penulis maupun rekan penulis menjadi lebih mudah dan dapat diakses kapan pun dan dimanapun serta oleh siapapun;

2) Pencarian peraturan - peraturan terkait kepegawaian dan keuangan menjadi lebih terpusat/ tidak tersebar kebeberapa website yang ada;

3) Peningkatan pemahaman serta peningkatan jumlah latihan bagi peserta ujian pengadaan barang/jasa pemerintah yang diharapkan seiring sejalan dengan peningkatan jumlah kelulusan peserta;

4) Lebih memudahkan peserta pelatihan atau yang membutuhkan terkait dengan simulasi pengembangan kompetensi ASN yang lebih interaktif;

5) Sebagai media informasi publik yang dapat meningkatkan wawasan/ pengetahuan masyarakat umum terkait dengan Pemerintah Provinsi DKI Jakarta.

Tujuan dari pelaksanaan kegiatan ini adalah :

3) Meningkatkan peran serta Widyaiswara dalam pelaksanaan pengembangan kompetensi;

4) Meningkatkan rasa keinginan untuk menulis dan berbagi informasi bagi Widyaiswara dan ASN lainnya secara keseluruhan;

5) Menjadi wadah Widyaiswara maupun ASN 


\section{Raden Yudhy Pradityo Setiadiputra. Pemanfaatan Teknologi Informasi Dalam Pelaksanaan Pembelajaran Dengan Media Website Dan Youtube Channel}

lainnya dalam menyalurkan Karya Tulis yang telah dihasilkan;

6) Meningkatkan media penunjang untuk pengembangan kompetensi ASN dan Masyarakat Umum;

7) Meningkatkan keseberaluasan informasi publik terkait dengan pengembangan kompetensi ASN;

8) Meningkatkan kualitas kompetensi ASN dalam kelulusan ujian barang/jasa;

9) Menjadi media informasi publik yang dapat meningkatkan wawasan/ pengetahuan masyarakat umum terkait dengan Pemerintah Provinsi DKI Jakarta.

Sasaran dari pelaksanaan kegiatan ini adalah seluruh Aparatur Sipil Negara, dan para peserta pengembangan kompetensi serta para Widyaiswara baik didalam maupun diluar Pemerintah Provinsi DKI Jakarta, serta masyarakat yang membutuhkan informasi terkait dengan bidang pemerintahan.

Materi yang digunakan dalam pelaksanaan kegiatan ini antara lain :

1) Pendistribusian bahan tayang, modul modul maupun artikel - artikel yang disusun oleh penulis maupun rekan penulis;

2) Pencarian peraturan - peraturan terkait kepegawaian dan keuangan;

3) Tryout Online ujian pengadaan barang/jasa tingat dasar dan Tryout Online CPNS;

4) Video simulasi pengembangan kompetensi ASN yang lebih interaktif

Setiadiputra (2017) dalam artikelnya menyatakan bahwa instansi pemerintah wajib memberikan pengembangan kompetensi kepada seluruh ASN yang terdapat di lingkungan instansi nya. Hal tersebut untuk meningkatkan serta tetap menjaga kualitas dari pelayanan pemerintahan, sehingga pemerintah dapat memenuhi kebutuhan masyarakat sesuai dengan cermat, cepat dan baik. Kompetensi adalah kemampuan kerja setiap sumber daya manusia yang mencakup aspek pengetahuan, keterampilan dan sikap kerja yang mutlak diperlukan dalam melaksanakan tugas tugasnya. Setiadiputra juga menyatakan dalam penelitiannya bahwa pengembangan kompetensi harus dilakukan secara terintegrasi sehingga dapat menciptakan pengembangan kompetensi yang berkualitas.

Dengan dilakukannya pelaksanaan pengembangan kompetensi diharapkan dapat meningkatkan kualitas pelayanan public kepada masyarakat yang dilakukan oleh setiap Aparatur Sipil negara (ASN). Hal ini terbukti atas penelitian yang dilakukan oleh Setiadiputra (2019), yaitu dengan dilakukannya pengembangan kompetensi pelaporan keuangan berbasis akrual dilingkungan Pemeirntah Provinsi DKI Jakarta memiliki peran dalam meningkatnya kualitas laporan keuangan Pemerintah Provinsi DKI Jakarta.

Dalam mencapai tujuannya tentu suatu organisasi memerlukan sumber daya manusia sebagai pengelola sistem, agar sistem ini berjalan tentu dalam pengelolaanya harus memperhatikan beberapa aspek penting seperti pelatihan, pengembangan, motivasi dan aspek-aspek lainya. Hal ini akan menjadikan manajemen sumber daya manusia sebagai salah satu indikator penting pencapaian tujuan organisasi secara efektif dan efisien. Berdasarkan hal tersebut diatas, maka dapat dikatakan bahwa sumber daya manusia merupakan asset organisasi yang sangat vital, karena itu peran dan fungsinya tidak bisa digantikan oleh sumber daya lainnya. Agar dapat tetap memenuhi kebutuhan organisasi, SDM harus selalu dikembangkan kualitas kompetensinya (Setiadiputra, 2017).

Seperti kita ketahui Bersama bahwa sata ini telah memasuki era disruptif teknologi yang merupakan suatu kenyataan ketika perkembangan teknologi berbasis digital ini berpotensi merubah struktur sosial secara radikal sebagai efek yang tak bisa dihindari. Setiadiputra (2017) menyatakan bahwa Untuk menjadi Disruptive technology diperlukan beberapa persyaratan, antara lain :

1) Inovasi baru tersebut tidak berkembang secara linier dengan teknologi sebelumnya;

2) Memanfaatkan peluang pasar yang muncul pada saat inovasi yang lama sudah terlalu canggih dan kompleks untuk sebagian pelanggan/stakeholder;

3) Inovasi yang dihasilkan bukanlah inovasi yang canggih namun dapat bersifat yang lebih inferior namun dapat lebih memuaskan pelanggan/ stakeholder.

Pada era teknologi 4.0 saat ini, perspektif dan inovasi sangat urgen untuk dimiliki para guru dalam menyentuh tiga kecakapan siswa yang mesti dipenuhi sekaligus: mentalitas yang tangguh mewakili etos kerja siap bersaing, kecakapan nalar tingkat tinggi berorientasi inovasi dan problem solving yang 


\section{Raden Yudhy Pradityo Setiadiputra. Pemanfaatan Teknologi Informasi Dalam Pelaksanaan Pembelajaran Dengan Media Website Dan Youtube Channel}

berbasis digitalisasi mewakili skill-kognitif, dan nilai kebijaksanaan sebagai benteng mewakili kepribadian/karakter.

\section{Metode}

Metode penelitian yang digunakan adalah metode kegiatan pengabdian. Metode atau kegiatan pengabdian ini merupakan implementasi langsung oleh penulis sebagai Widyaiswara. Dan melibatkan beberapa rekan Widyaiswara sebagai kontributor konten / materi dari website serta bekerja sama dengan BPSDM Provinsi DKI Jakarta terkait pengembangan dan pembuatan video simulasi interaktif.

\section{Hasil Dan Pembahasan}

Pemanfaatan Teknologi Informasi dalam Pelaksanaan Pembelajaran dengan Media Website dan Youtube Channel yang telah dilaksanakan sejak Agustus 2016 sampai dengan saat ini, telah mempunyai beberapa hasil dan manfaat dalam pengembangan kompetensi di lingkungan BPSDM Pemerintah Provinsi DKI Jakarta. Selama pelaksanaan pembangunan website Pojok Informasi Aparatur di 2 (dua) tahun terakhir, cukup berkembang secara signifikan dan sangat dirasakan manfaatnya oleh para peserta pengembangan kompetensi. Berikut disampaikan beberapa hasil dan manfaat pelaksanaan pembangunan website Pojok Informasi Aparatur, antara lain :

1) Sebagai wadah para Widyaiswara dan peserta pengembangan kompetensi dalam mengakses bahan tayang yang disusun dan disampaikan penulis pada kegiatan dikjartih.

Dimana dengan adanya website Pojok Informasi Aparatur ini, memudahkan bagi para widyaiswara ataupun narasumber serta para peserta pelatihan dalam emndapatkan bahan tayang/ materi ajar yang diperlukan, bahkan dapat diunduh sebelum materi disampaikan langsung oleh para widyaiswara atau narasumber. Hal ini mengakibatkan para peserta akan memiliki wawasan yang lebih saat materi berlangsung. Seperti yang terdapat pada gambarl dibawah ini.
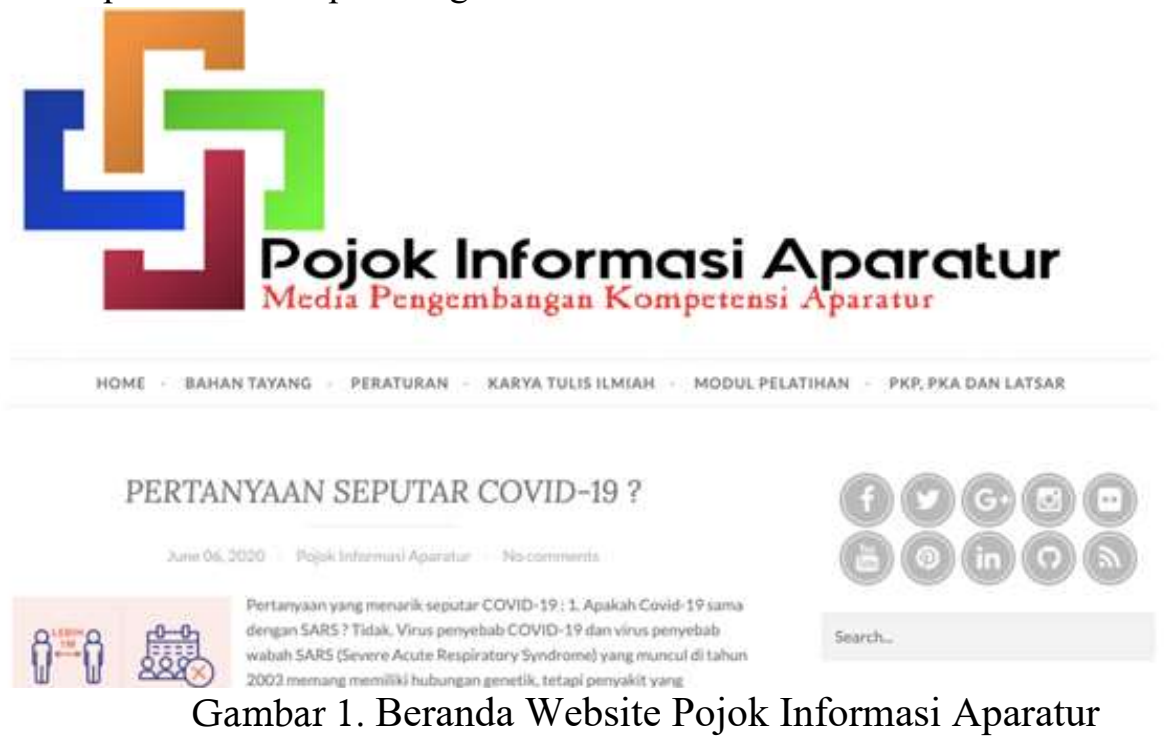

2) Sebagai wadah media informasi terkait informasi bidang pemerintahan, yang terdiri dari peraturan -peraturan, laporan - laporan pertanggungjawaban pemerintah daerah (khususnya Pemprov DKI Jakarta), Data data Statistik terkait Pemprov DKI Jakarta yang dimana penulis bekerja sama dengan BPS Provinsi DKI Jakarta tekkait dengan penyediaan data - data statistik

3) Sebagai wadah kumpulan Karya Tulis Ilmiah dari berbagai literatur yang dapat dipertanggungjawabkan.

Saat ini seperti kita ketahui bahwa setiap jabatan fungsional tak terkecuali dosen dan widyaiswara, memiliki kewajiban dalam 


\section{Raden Yudhy Pradityo Setiadiputra. Pemanfaatan Teknologi Informasi Dalam Pelaksanaan Pembelajaran Dengan Media Website Dan Youtube Channel}

pelaksanaan pengembangan profesinya yaitu harus menulis artikel yang diterbitkan dalam sebuah jurnal ilmiah. Namun masih banyak para widyaiswara yang mungkin belum familiar dengan bentuk artikel ilmiah. Berdasarkan hal tersebut website Pojok Informasi Aparatur bermaksud untuk iumpuLANiKarYa TULISILMUNA

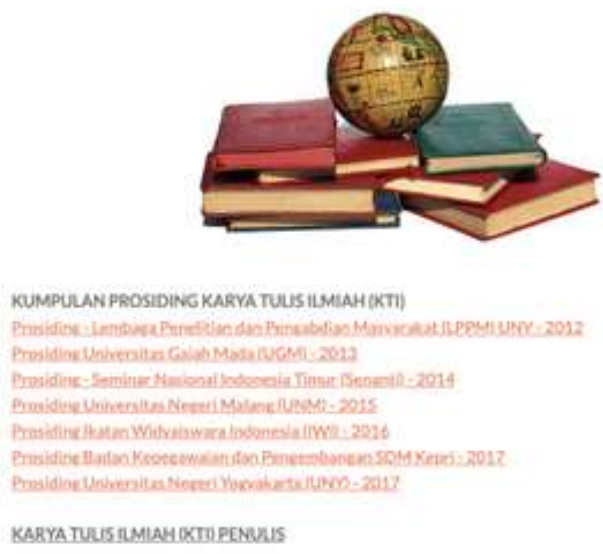

Gambar 2. Menu Karya Tulis memudahkan para widyaiswara atau yang membutuhkancontoh artikel unutk dapat mengunduhnya, seperti yang terlihat dalam gambar 2 dibawah ini.
4) Sebagai wadah bagi penulis dalam mengembangkan minat menulis dan mengekspresikan penulis dalam bentuk tulisan (unsur penunjang)

5) Sebagai wadah Tryout Online Ujian Pengadaan Barang/Jasa Tingkat Dasar dan Tryout Online CPNS.

Di lingkungan Pemerintah Provinsi DKI Jakarta saat ini sudha diwajibkan bahwa setiap pejabat structural diwajibkan memiliki sertifikat ahli pengadaan barang jasa pemerintah tingkat dasar. Berkenaan

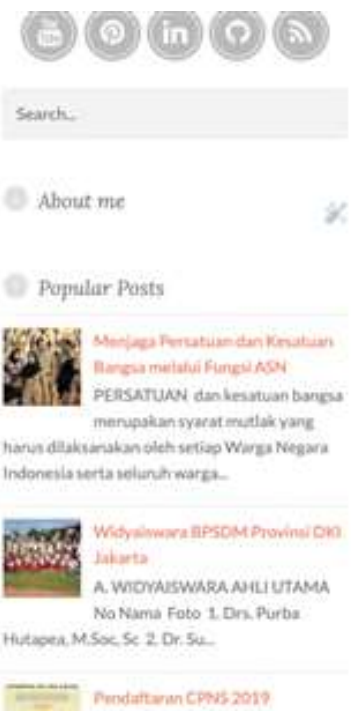

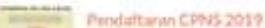

Try Out Online Pengadaan Barang/Jasa

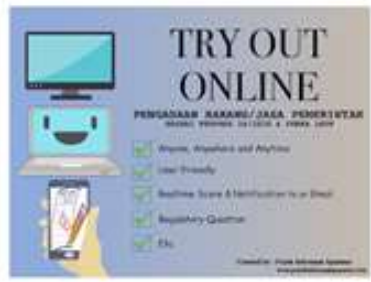

dengan hal tersebut semakin tinggi pula minta para pejabat structural untuk dapat lulus dan memiliki sertifikat ahli pengadaan barang jasa pemerintah tingkat dasar tersebut. Tryout online ini bermaksud memudahkan para calon peserta ujian sertifikat ahli pengadaan barang jasa pemerintah tingkat dasar dalam belajar atau latihan soal terkait ujian pengadaan barang/jasa tersebut sebagai mana hal ini dapat dilihat dalam Gambar 3 berikut.

- SOAL TRY OUT - TIPEA - SOALTRYOUT - TIPEB -SOALTRY OUT-TIPEC
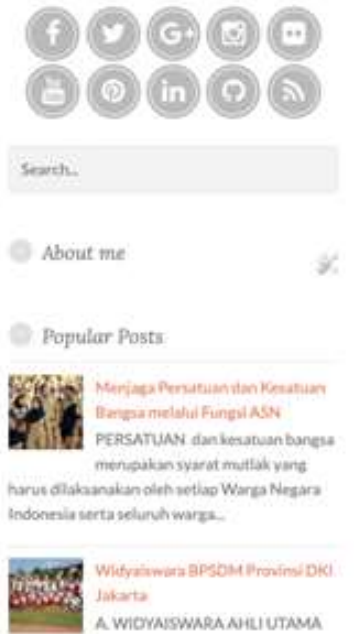

an Barang/Jasa 


\section{Raden Yudhy Pradityo Setiadiputra. Pemanfaatan Teknologi Informasi Dalam Pelaksanaan Pembelajaran Dengan Media Website Dan Youtube Channel}

Selain website, Pojok Informasi Aparatur sejak pertengahan tahun 2019 telah memiliki Youtube Channel sebagai salah satu media penunjang yang digunakan sebagai wadah yang lebih interaktif agar para pengguna informasi lebih memahami. Berikut disampaikan beberapa hasil dan manfaat pelaksanaan penggunaan Youtube Channel Pojok Informasi Aparatur, antara lain :

1) Sebagai wadah media interaktif bagi para peserta pengembangan kompetensi, maupun para pengguna informasi secara umum. Selain dengan website yang lebih bersifat satu arah, telah dikembangkan pula video learning yang lebih bersifat nyata atau dua arah, melalu Youtube Channel Pojok Informasi Aparatur yang dimana terdapat berbagai macam video seperti microlearning, sharing knowledge dan lain sebagainya seperti yang terdapat pada Gambar 4 dibawah ini.

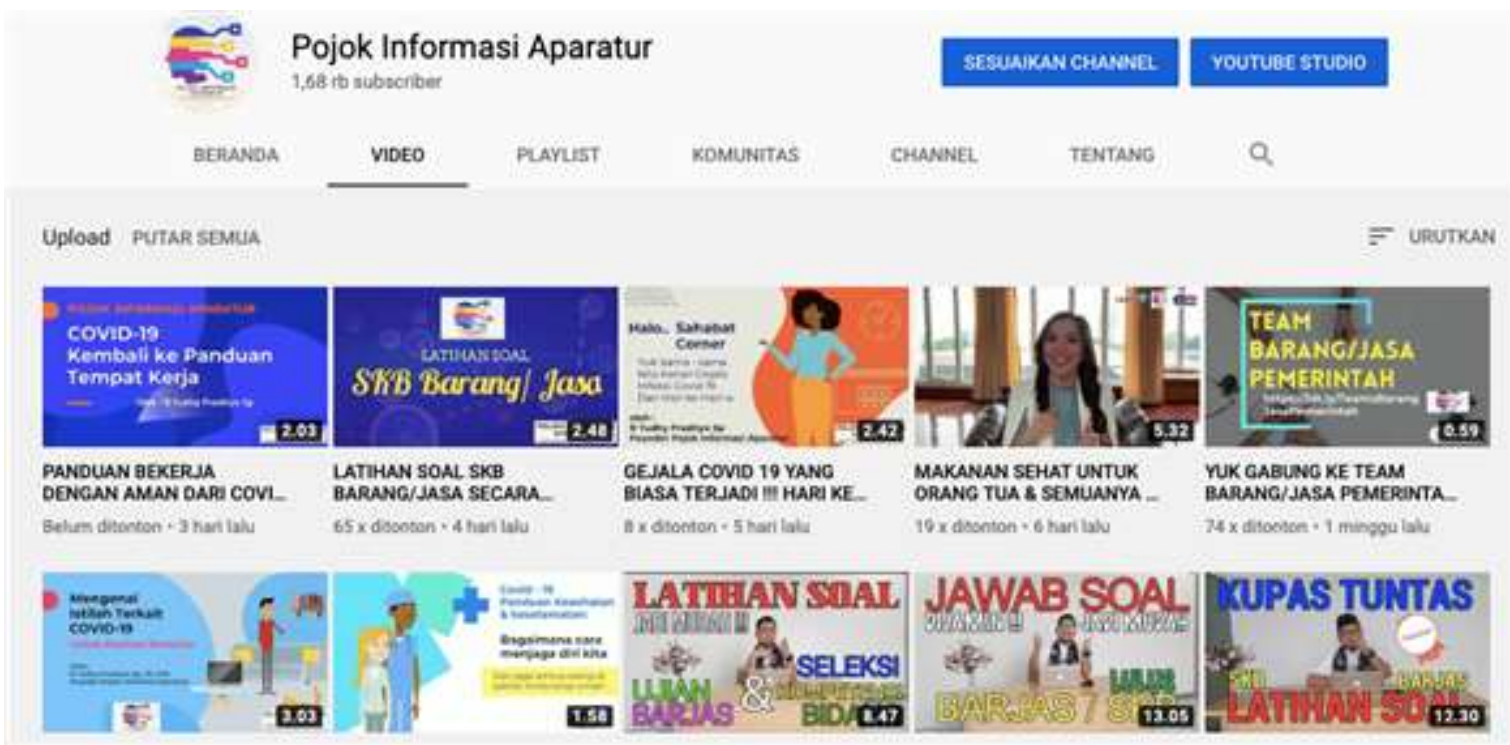

Gambar 4. Youtube Channel Pojok Informasi Aparatur

2) Sebagai wadah pendistribusian karya karya pelaksanaan pengembangan kompetensi

Saat ini dikarenakan kesulitannya wadah unutuk mengapresiasi atau sekedar memajang hasil karaya para peserta pelatihan, maka di Youtube Channel ini juga dapat menampilkan karya - karya pelaksanaan pengembangan kompetensi sehingga mereka akan merasa lebih dihargai karyanya oleh orang lain dan sebagai bagian dari membiasakan sharing knowledge kepada orang lain, seperti yang terlihat dalam Gambar 5 dibawah ini. 
Raden Yudhy Pradityo Setiadiputra. Pemanfaatan Teknologi Informasi Dalam Pelaksanaan Pembelajaran Dengan Media Website Dan Youtube Channel

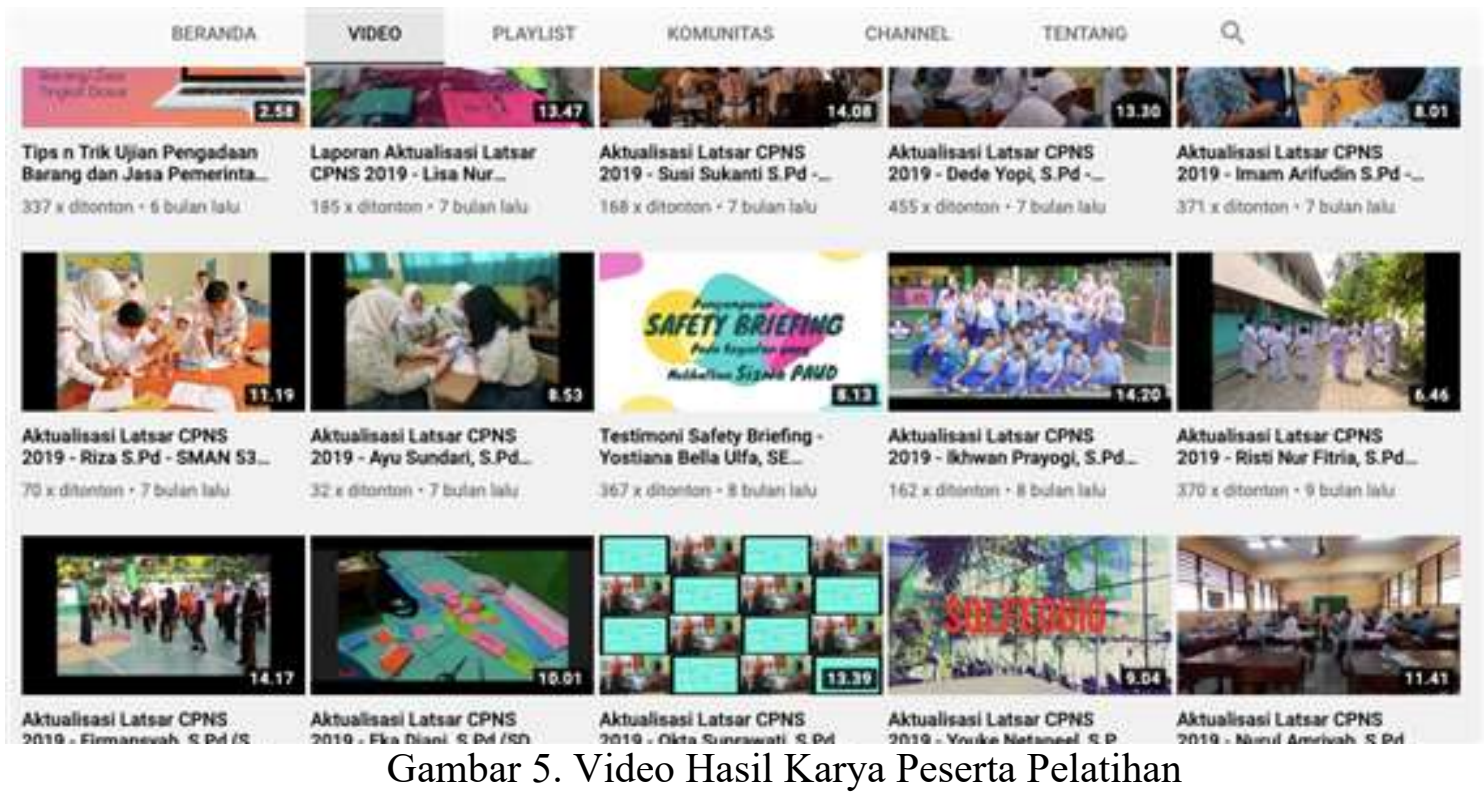

Setelah dilaksanakan pemanfaatan Pemanfaatan Teknologi Informasi dalam Pelaksanaan Pembelajaran dengan Media Website dan Youtube Channel selama kurang lebih 3 (tiga) tahun ini, kedepannya terdapat beberapa tantangan yang diprediksi akan dihadapi, antara lain :

1) Konsistensi dalam pengisian konten konten yang menarik dna lebih bermanfaat bagi ASN maupun masyarakat secara umum;

2) Selalu update teknologi informasi khususnya dibidang pembelajaran;
3) Pengelolaan sumber daya yang sesuai porsinya (baik SDM, SD lainnya guna menunjang pelaksanaan pemanfaatan teknologi informasi);

4) Masih banyaknya ASN yang belum terlalu menguasai teknologi informasi

Berikut disampaikan beberapa dokumentasi saat pelaksanaan penyusunan konten video ataupun konten video yang terdapat daam Youtube Channel Pojok Informasi Aparatur, antara lain :

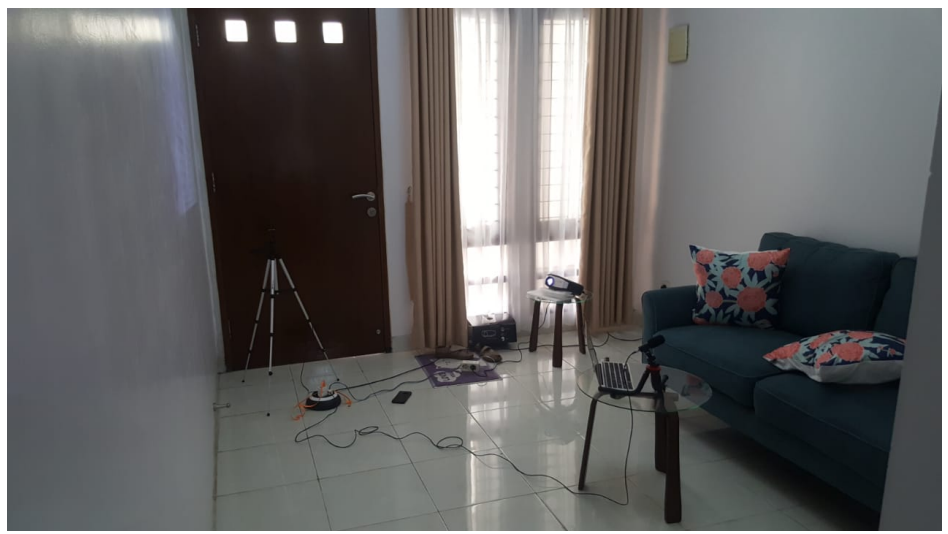

Gambar 6 Kondisi ruangan saat shooting video konten 

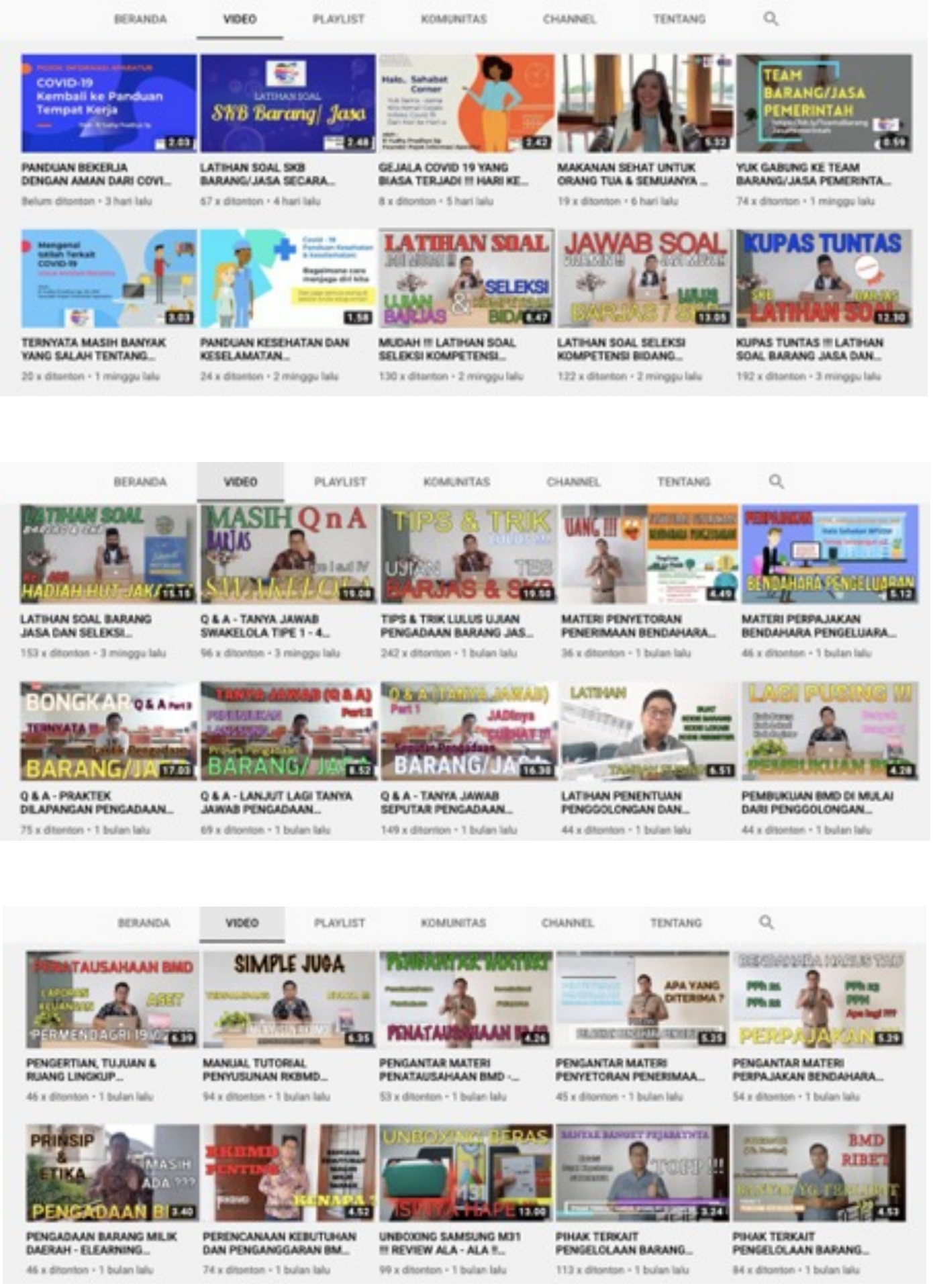


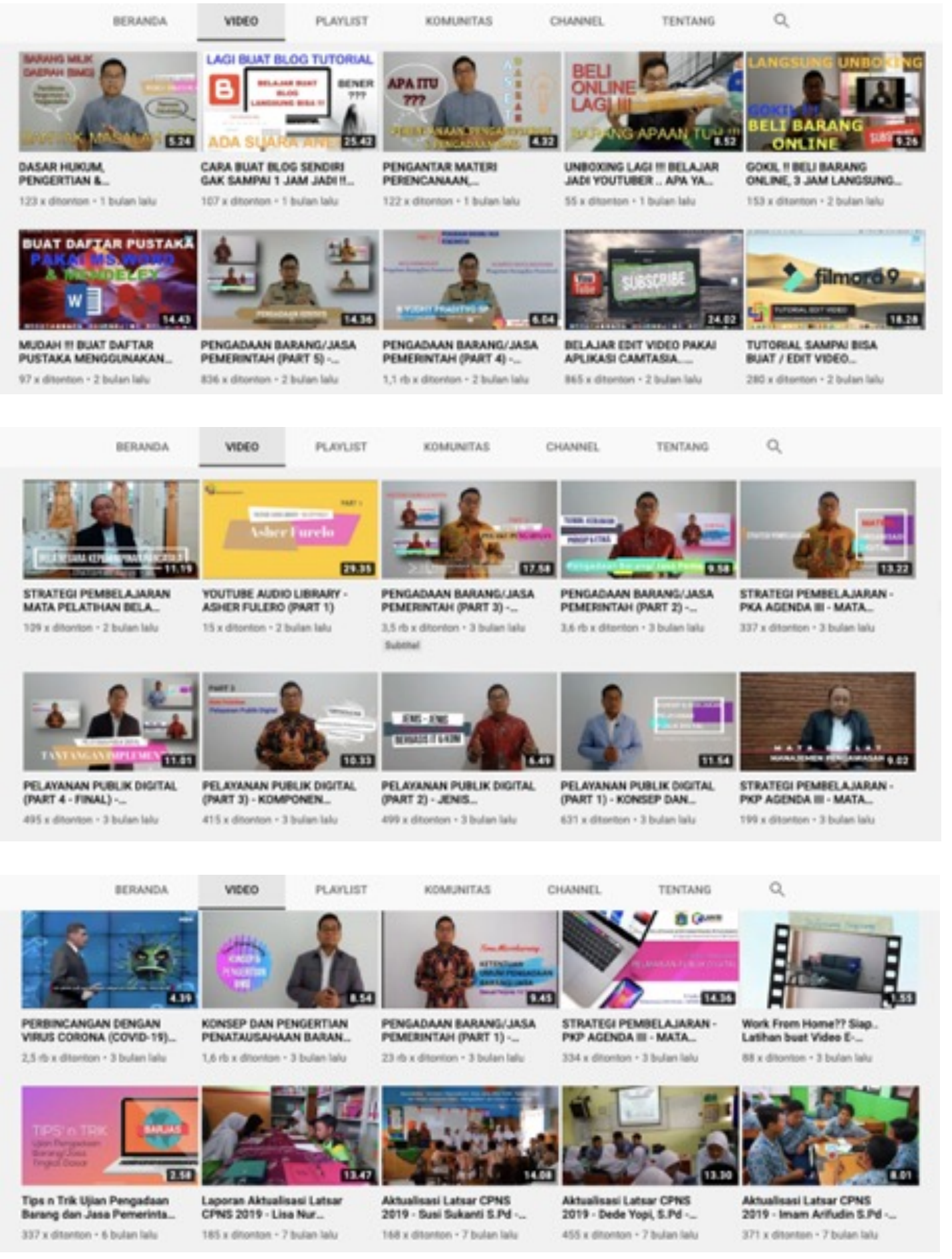




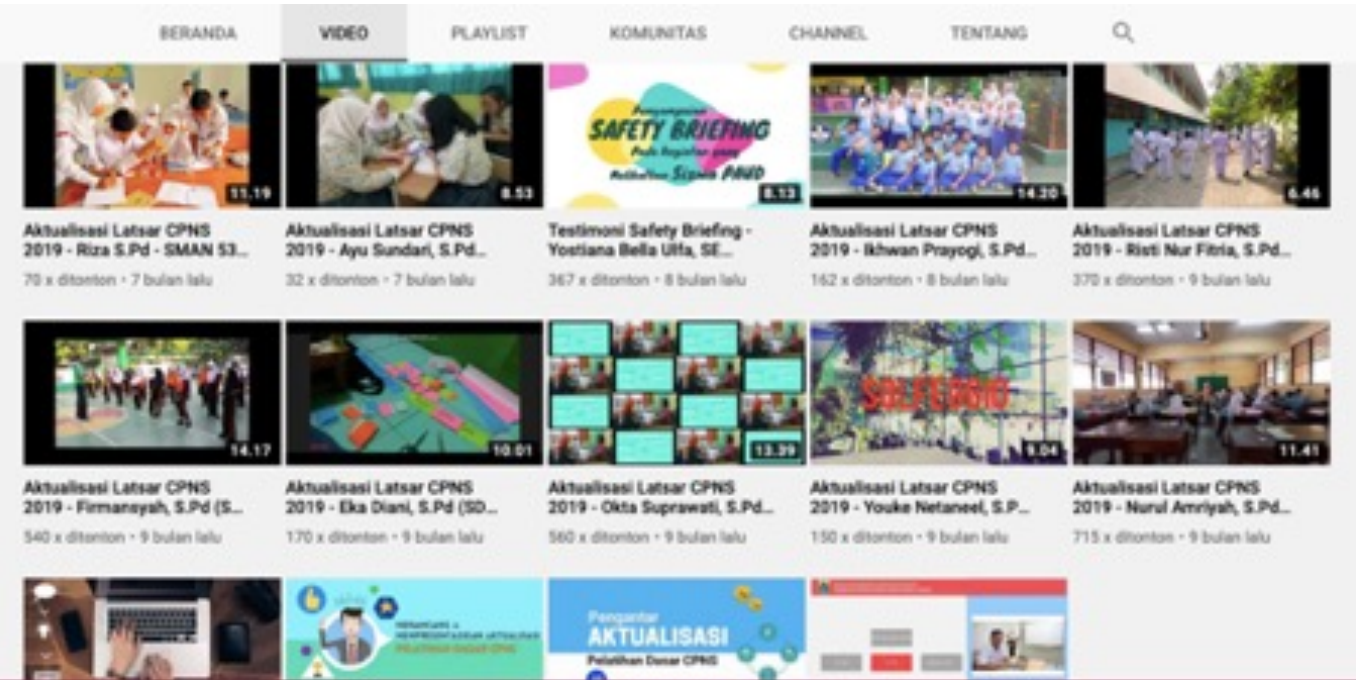

Gambar 7. Kumpulan Konten Video dalam Youtube Channel

Modul Pelatihan Dasar Calon Pegawai Negeri Sipil
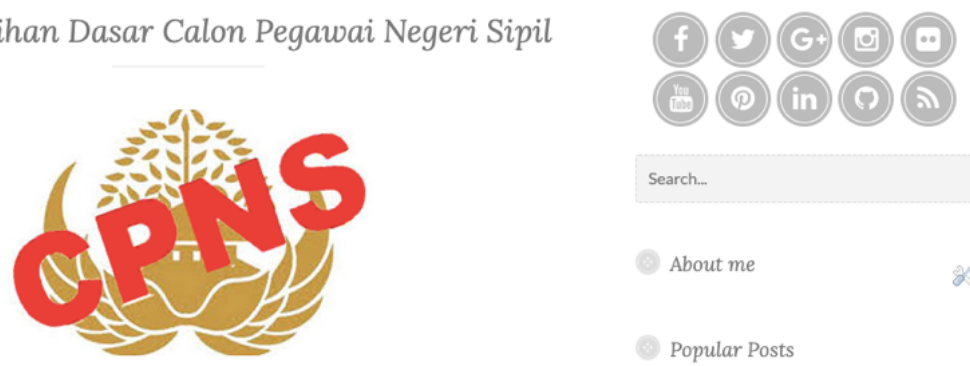

Pelatihan Dasar CPNS - Golongan III

Peraturan Kepala LAN 12 Tahun 2018 tentang Pelatihan Dasar Calon PNS

Agenda I

Modul Latsar - Wasbang dan Nilai Bela Negara

Modul Latsar - Kesiapsiagaan Bela Negara

Modul Latsar - Analisis I su Kontemporer

Arenda II

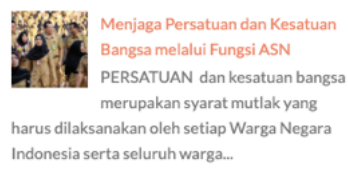

Hoxy

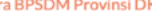

A. WIDYAISWARAAHUUTAMA No Nama Foto 1. Drs. Purba

Materi Pengadaan Barang Jasa Pemerintah
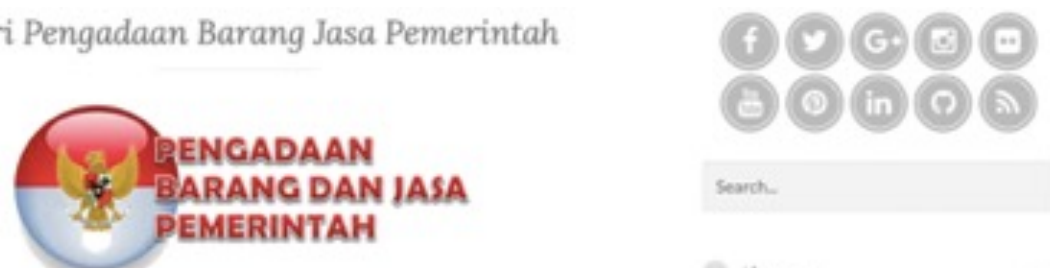

Nhout me

Veceri. Ketsethus Unumva

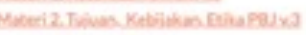

Meceria Pribu Pedx 3

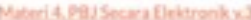

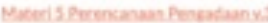

Meteris Provion PAIxa

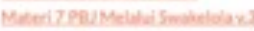

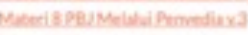

Meseriy Pmediden Roveav?

Lathen Sad-01 Soal Troout Wet?

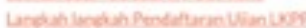

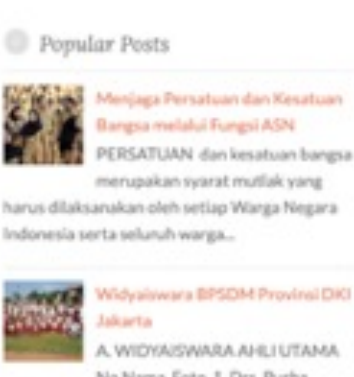

Na Numa Foto 1 Dirs. Purbs

Gambar 8. Kumpulan Materi dalam Website 


\section{Simpulan Dan Saran}

Sumber daya manusia merupakan salah satu aset terpenting bagi perkembangan setiap organisasi. Hal tersebut termasuk bagi organisasi pemerintah wajib berkembang sesuai dengan kebutuhan perkembangan zaman untuk selalu dapat memenuhi kebutuhan para masyarakat. Organisasi pemerintah dibentuk sebagai organisasi pelayan masyarakat untuk memenuhi semua kebutuhan masyarakat terkait dengan pelayanan kepemerintahan. Untuk memenuhi semua kebutuhan tersebut, ASN sebagai SDM dari organisasi pemerintah harus ikut berkembang kompetensi yang dimilikinya. Pengembangan kompetensi ASN saat ini harus mengikuti perkembangan teknologi informasi agar pelaksanaannya semakin cepat, tepat dan lebih efektif serta efisien.

Sebagai salah satu bentuk dukungan penulis dalam pelaksanaan pengembangan kompetensi ASN yang mengikuti perkembangan teknologi informasi, penulis telah melaksanakan Pemanfaatan Teknologi Informasi dalam Pelaksanaan Pembelajaran dengan Media Website dan Youtube Channel. Pemanfaatan teknologi informasi tersebut telah dilaksanakan kurang lebih selama 3 (tiga) tahun sejak Agustus 2016 sampai dengan saat ini. Terdapat banyak hasil dan manfaat dari pemanfaatan teknologi informasi tersebut.

Berdasarkan beberapa hal yang telah disampaikan sebelumnya, maka terdapat beberapa saran / masukan yang ingin penulis sampaikan :

1) Bagi Instansi Pelaksana Pengembangan Kompetensi

a. Adanya monitoring dan evaluasi rutin yang dilaksanakan terhadap pelaksanaan pengembangan kompetensi untuk mengetahui tindak lanjut / hasil dari pelaksanaan pengembangan kompetensi;

b. Pelaksanaan pengembangan kompetensi yang mengikuti era teknologi digitalisasi dengan tetap memperhatikan kualitas hasil dari pelaksanaannya;

2) Bagi Widyaiswara

a. Upaya untuk meningkatkan minat menulis bagi para Widyaiswara, karena
Widyaiswara harus dapat selangkah lebih maju dari para peserta pengembangan kompetensi;

b. Selalu meningkatkan semangat berbagi / sharing knowledge untuk semua.

3) Bagi Peserta dan Masyarakat Umum lainnya.

Manfaatkan era teknologi informasi saat ini dengan positif, sehingga dapat meningkatkan pula kualitas SDM dari pelaksanaan pengembangan kompetensi yang ada.

\section{Daftar Rujukan}

Setiadiputra, Yudhy Pradityo. Urgensi Program Pengembangan Kompetensi Sdm Secara Berkesinambungan Di Lingkungan Instansi Pemerintah. Jurnal Sawala. Volume V No 1. 2017

Setiadiputra, Yudhy Pradityo. Peran Pengembangan Kompetensi Pelaporan Pengelolaan Keuangan Berbasis Akrual Terhadap Penyusunan Laporan Keuangan Pemerintah Daerah. Monas:Jurnal Inovasi Aparatur. Volume 1 No 1.2019

Setiadiputra, Yudhy Pradityo. Pemanfaatan Real Time Conference Dalam Bidang Pengembangan Kompetensi Pada Era Disruptive Technology. Jurnal Jendela Inovasi Daerah. Volume II No 2. 2019

Undang - Undang Nomor 5 Tahun 2014 tentang Aparatur Sipil Negara

Peraturan Pemerintah Nomor 11 Tahun 2017 tentang Manajemen Pegawai Negeri Sipil

Peraturan Menteri PAN-RB Nomor 22 Tahun 2014 tentang Jabatan Fungsional Widyaiswara dan Angka Kreditnya;

Peraturan Bersama Kepala LAN Nomor 1 Tahun 2015 dan Kepala BKN Nomor 8 Tahun 2015 tentang Ketentuan Pelaksanaan PermenPAN-RB Nomor 22 Tahun 2014 tentang Jabatan Fungsional Widyaiswara dan Angka Kreditnya;

Peraturan Kepala LAN Nomor 26 Tahun 2015 tentang Pedoman Penilaian Angka Kredit Jabatan Fungsional Widyaiswara; 